\title{
A comparison of soil chemical characteristics in modified rangeland communities
}

\author{
JOHAN F. DORMAAR AND WALTER D. WILLMS
}

Authors are soil scientist (retired) and range ecologist, Research Centre, Agriculture and Agri-Food Canada, P0 Box 3000, Lethbridge, Alberta, Canada TIJ $4 B 1$.

\section{Abstract}

The effects of converting native prairie to simplified agronomic communities on primary production and soil quality are expected to differ over the short-term. A study was initiated at 4 locations: a Mixed Prairie with Stipa comata Trin. \& Rupr. dominant in the Brown Soil Zone (1994), a Mixed Prairie with S. comata and $S$. viridula Trin. dominant in the Dark Brown Soil Zone (1993), and 2 in the Fescue Prairie with Festuca campestris Rydb. dominant in the Black Soil Zone (1993). At each of the 4 sites, 5 treatments representing common production systems were seeded as monocultures [ 2 grass species, alfalfa (Medicago sativa $\mathbf{L}$. 'Beaver'), and 2 spring wheat (Triticum aestivum L. 'Katepwa) seeded as either continuous or as wheat-fallow], and 1 treatment consisting of abandoned cultivation were compared with a native community in a randomized complete block design with 4 replicates. One site in the Black Soil Zone was an overgrazed prairie (2.4 animal unit month ha-1 since 1949) and a second was mostly ungrazed for the previous 50 years with occasional light fallgrazing. Soils of the modified communities were different $(P<$ 0.05) than of the native community with respect to percent carbon and nitrogen, concentration of monosaccharides, and concentration of most phosphorus constituents. Modifying the community through cultivation and seeding usually caused a reduction in the measured variable except for $\mathrm{NaHCO}_{3}$ inorganic phosphorus that increased. Cultivation rather than the plants of the new community was believed responsible for most of the observed changes in $\mathrm{C}, \mathrm{N}$, and various $\mathrm{P}$ fractions and the loss of water-stable aggregates remaining on the 2.0 and $1.0 \mathrm{~mm}$ sieves. Although the contribution of seeded species on the chemical and physical characteristics would not have been significantly expressed in 2 to 3 years and many more years would be required to reach a steady state, monosaccharide distribution had nevertheless started to shift to one that was plant-affected.

Key Words: steady state, monoculture, Mixed Prairie, fescue prairie, phosphorus, soil-plant interaction

The production-oriented goals of agriculture have resulted in tremendous changes in land-use on the prairies. A number of grass species have been introduced over the years, such as crested wheatgrass (Agropyron cristatum (L.) Gaertn.), Russian wildrye

The authors gratefully acknowledge financial support from the Alberta Agriculture Research Institute and the assistance of R. G. Gschaid, with establishing the plots, and B. C. Tovell and L. Cramer in carrying out the laboratory analyses. Lethbridge Research Centre Contribution No. 3879923

Manuscript accepted 23 Oct. 1999.

\section{Resumen}

Es de esperar que el efecto de convertir pasturas nativas a comunidades agronóinicas simples en producción priinaria y calidad de suelo, difieran a corto térrnino. Fue iniciado un estudia en cuatro sitios: una Pradera Mixta con Stipa comata Trin. \& Rupr. dominante en la zona de suelos castafios (1994), una Pradera Mixta con $S$. comata y $S$. viridula Trin. dominante en La zona de suelos castaflo oscuro (1993) y dos en la zona de Praderas con Festucas, siendo Festuca campestris Rydb. La dominante de la zona de suelos negros (1993). En cada de los cuatro sitios, se implementaron cinco tratamientos representativos de los sistemas de producción más comunes como monocultivos [dos especies de gramineas. alfalfa (Medicago sativa $\mathbf{L}$. 'Beaver') y dos de trigo de primavera (Triticum aestivuin $\mathbf{L}$. 'Katepwa') sembrados en forma continua o como trigo-barbecho] y un tratamiento consistente en un cultivo abandonado comparándolo con una comunidad de plantas nativas en un diseflo de bloque seleccionado completainente al azar con cuatro niplicas. Un sitio en la zona de suelo negro fue una pradera sobrepastoreada $(2,4$ unidades animal por mes y por ha desde 1949) y el segundo sitio fuee prácticamente no pastoreado en los previos 50 años con pastoreos otoñales ocasionales. Los suelos de las comunidades modificadas fueron diferentes $(P<0.05)$ de las comunidades nativas con respecto al porcentaje de carbón y nitrógeno, la concentración de monosacáiridos y la concentración de la mayoria de los constituyentes del fósforo. la modificación de la comumdad a través de la cultivación y el sembrado generalmente causó una reducción en las variables medidas, excepto por el $\mathrm{CO}_{3} \mathrm{NaH}$ fósforo inorgánico el cual aumentó. Se cree que la cultivación más que las plantas de la nueva comunidad fueron las responsables por la mayoria de los cambios observados en $\mathrm{C}$, $\mathrm{N}$ y varias fracciones de $\mathrm{P}$ y la pérdida de agregados de agua-estable retenido en los tamizes de $2.0 \mathrm{~mm}$ y de $\mathbf{1 . 0}$ mm. Aunque la contribución de especies sembradas en las caracteristícas químicas y fisicas no hubieran sido significadamente expresadas en 2 ó 3 años y muchos más años serian necesarios para llegar a una situación estable, sin embargo la distribución de monosacáiridos empezo a cambiarse hacia uno que era afectado por la planta.

(Elymus junceus Fisch.), smooth bromegrass (Bromus inermis Leyss.) and orchard grass or cock's foot (Dactylis glomerata L.). Other areas have been cultivated to grow wheat (Triticum aes tivum L.) and alfalfa (Medicago sativa L.). Changes in soil quality by converting the native prairie to monocultures might be expected if the hypothesis is accepted that the prairie has devel- 
oped for optimal exploitation of the environment and any changes are retrogressive (Porter et al. 1996). However, evidence is lacking on which to base definitive conclusions. The effects of converting native prairie to monoculture systems, on primary production and soil quality, are expected to differ over the short- and long-terms. It is hypothesized that above-ground production of seeded forages and cereals will be greater than that of native range in the first few years after establishment while indices of soil quality, such as organic matter and water stable aggregates, will have been transformed. However, in the long-term, i.e., more than 10 years, aboveground production may well be similar while the rate of deterioration in soil quality may decrease. This research examines the short-term adjustments to soil disturbances.

For the study reported here, we hypothesized that the inherent or natural quality of range soils is immediately affected by the introduction, via cultivation, of monocultures. Organic $\mathrm{C}$ and $\mathrm{N}$, monosaccharides, $\mathrm{P}$, and water-stable aggregate fractions that remain on the 2.0 and $1.0 \mathrm{~mm}$. sieves $(>2.0+>1.0 \mathrm{~mm})$ were selected as important indicators of soil quality. Carbon and $\mathrm{N}$ have been studied in various grassland systems but the fate of $\mathrm{P}$ is relatively unknown (Schimel et al. 1985). Conversion of native grasslands to agronomic communities is expected to alter their composition in the soil, but at some time a new steady state will be reached. Steady states are generally only established in plots approaching 50-100 years such as the Rothamsted, Sanborn, and Morrow plots (Jenkinson 1991, Mitchell et al. 1991). This study attempts to establish a time frame as to when vegetation effects will start to synergise with cultivation effects leading to a new steady state.

\section{Materials and Methods}

\section{Site Description}

The study was conducted at 4 sites in southern Alberta. One site was at the Agriculture and Agri-Food Canada Substation at Onefour $\left(49^{\circ} 03^{\prime} \mathrm{N} 110^{\circ} 27^{\prime} \mathrm{W}\right)$ with average precipitation of $310 \mathrm{~mm}$, Orthic Brown (Aridic Haplustoll) soils, and a Stipa-Bouteloua faciation in the Mixed Prairie. The second site was at the Animal Diseases Research Institute (ADRI) near Lethbridge $\left(49^{\circ} 43^{\prime} \mathrm{N}\right.$ $112^{\circ} 58^{\prime} \mathrm{W}$ ) where average precipitation is $420 \mathrm{~mm}$; the soils are Orthic Dark Brown (Typic Haplustoll) and the plant communi- ty is a Stipa-Bouteloua-Agropyron faciation in the Mixed Prairie. The third and fourth sites were at the Agriculture and AgriFood Canada Substation west of Stavely in the Porcupine Hills $\left(50^{\circ} 11^{\prime} \mathrm{N} 113^{\circ}\right.$ $58^{\prime} \mathrm{W}$ ) with an average precipitation of 550 mm, Orthic Black (Typic Hapludoll) soils and in a fescue grassland dominated by rough fescue (Festuca campestris Rydb.). One of the Fescue Prairie sites was grazed at 2.4 animal unit month ha $^{-1}$ since 1949 and the second was mostly ungrazed for the prior 50 years but experienced occasional light grazing in fall. The vegetation of all 4 sites has been described by Moss and Campbell (1947) and Coupland (1961). Each site was enclosed with a 4strand barbed-wire fence that excluded livestock.

\section{Methods}

At each site, 7 treatments representing common production practices were imposed and compared with the native community in a randomized complete block design with 4 replicates. The plot size was $3 \times 10 \mathrm{~m}$. The treatments were: 1 ) native prairie, 2) crested wheatgrass (Agropyron cristatum (L.) Gaertn.) on the Mixed Prairie sites (Onefour and Lethbridge) and orchard grass (Dactylis glomerata L.) on the Fescue Prairie sites, 3) Russian wildrye (Elymus junceus Fisch.) on the 2 Mixed Prairie sites (Onefour and Lethbridge) and smooth bromegrass (Bromus inermis Leyss.) on the Fescue Prairie sites, 4) spring wheat and fallow in rotation, 5) continuous spring wheat (Triticum aestivum L. 'Katepwa'), 6) alfalfa (Medicago sativa $\mathrm{L}$. Beaver'), 7) abandoned cultivated land to allow natural succession. In the grazed Fescue Prairie site, an $8^{\text {th }}$ treatment was included that consisted of a native community (Treatment 8 ) outside the exclosure to allow a comparison of recovering grazed prairie within the exclosure.

All plots were established in spring (Dormaar and Willms 2000) by cultivating and seeding. Following cultivation, the plots were raked to remove excessive plant mass to emulate the seedbed of a well-established cultivated field. At the end of each growing season, the above ground biomass of all seeded plots was mowed to a $5-\mathrm{cm}$ height and removed. The abandoned plot was cultivated several times during the first summer and plants that emerged from live tillers were removed until the second year. All seedings were in a $15-\mathrm{cm}$ row spacing. The
Stipa-Bouteloua-Agropyron and Fescue Prairie sites were prepared and established in spring 1993 and the Stipa-Bouteloua site was established in spring 1994.

Soil samples were taken on 22 April 1 May, and 6 June 1996, on the StipaBouteloua, Stipa-Bouteloua-Agropyron, and Fescue Prairie sites, respectively. Three subsamples were taken from each plot from either the Ah(=A1) or Apj soil horizon, composited and hand-sieved in the field through a 2-mm screen. Separate samples were obtained for the determination of water-stable aggregates by passing them through an 8-mm screen in the field. Following air-drying, water-stable aggregates that had been wetted by capillarity were obtained by the wet-sieving technique using the total sample (Kemper and Koch 1966; Kemper and Rosenau 1986). Only the water-stable aggregate fractions that remained on the 2.0 and $1.0 \mathrm{~mm}$. sieves $(>2.0+>1.0 \mathrm{~mm})$ as a percent of the sum of all water-stable aggregates measured, were reported as it was the most meaningful comparison at the early stage of this long-term experiment.

Since soil samples were taken either from the genetic Ah horizon $(8-12 \mathrm{~cm}, 10$ $-14 \mathrm{~cm}, 20-24 \mathrm{~cm}$, and $10-14 \mathrm{~cm}$ thick for the Brown, Dark Brown, Black-ungrazed and Black-grazed Chernozemic soils, respectively) or the cultivated Apj horizon (i.e., 20-22 cm thick), and since most of the root mass was raked off following seedbed preparation, bulk densities were not considered to be meaningful.

Total $\mathrm{C}$ and $\mathrm{N}$ were determined by dry combustion in a Carlo Erba NA 1500 Analyzers. Acid hydrolysis was carried out essentially as outlined by Cheshire and Mundie (1966) and Cheshire (1979) except that the samples were first treated with $12 \mathrm{M} \mathrm{H}_{2} \mathrm{SO}_{4}$ for 16 hours at room temperature, then diluted to $0.5 \mathrm{M} \mathrm{H}_{2} \mathrm{SO}_{4}$ and held at $100^{\circ} \mathrm{C}$ for 1 hour (Dormaar 1984). Monosaccharides were reduced and acetylated as described by Blakeney et al. (1983). D-allose was added as the internal standard. The alditol acetates were identified with a Hewlett Packard GC 5840A equipped with a hydrogen flame ionization detector and a $30-\mathrm{m}$ long glass capillary column $(0.25$ mm id.) wall-coated with OV-225 (50\% cyanopropyl-50\% methylphenylpolysiloxane) with helium as the carrier gas at a linear flow rate of $21 \mathrm{~cm} \mathrm{sec}^{-1}$. Reference alditol acetates of rhamnose, fucose, ribose, arabinose, xylose, allose, mannose, galactose, and glucose were used as standards and prepared as outlined by Blakeney et al. (1983). Polysaccharides are considered to have a plant origin if they contain substantial 
quantities of arabinose and xylose and predominantly of microbial origin if they contain mainly galactose and mannose (Cheshire 1979).

Phosphorus is the one major constituent of soil organic matter that must be supplied entirely from the parent material. Since loss of soil P on the Fescue Prairie was of concern (Dormaar and Willms 1998), there is a need to better understand soil $\mathrm{P}$ under various plant communities. Hence, changes in labile inorganic (Pi) and organic $(\mathrm{Po})$ fractions were studied using a simplified modification of the sequential extraction technique (Hedley et al. 1982). Only resin, extractable $\mathrm{Pi}$, $\mathrm{NaHCO}_{3}$-extractable $\mathrm{Pi}$ and $\mathrm{Po}$ and $\mathrm{NaOH}-$ extractable Pi and Po of unlysed resin-treated soil were determined as well as total soil P.

The treatment effect was analysed in a single model including site, with replicates nested in site, to evaluate the site by treatment interactions for each variable. In each instance, the interaction was significant $(\mathrm{P}<0.05)$ and the analysis was repeated by site. Selected site and treatment comparisons were made using single-degree of freedom contrasts (Steel and Torrie 1980) of planned comparisons.

For the chemical analysis, 3 comparisons were considered, i.e., native prairie vs. cultivation, native prairie vs. introduced forage grasses, and introduced forage grasses vs. continuous wheat since there is much debate in the literature regarding the effect of these grasses on soil chemical properties. An additional comparison of native prairie vs. abandoned cultivated land was carried out for the water-stable aggregates.

\section{Results}

Site effects were significant for each variable tested and, with 3 exceptions, each variable was different between each paired site. Only total $\mathrm{N}$ and sodium hydroxide-extractable total and organic phosphorus, were similar between the grazed and ungrazed Fescue Prairie sites (Tables 1 and 2). The values of each constituent tended to follow the order of mag-

Table 1. The influence of cultivation and modified plant communities on selected soil parameters.

\begin{tabular}{|c|c|c|c|c|c|c|c|c|c|c|c|c|}
\hline & \multirow[t]{2}{*}{$\mathrm{C}$} & \multirow[t]{2}{*}{$\mathrm{N}$} & \multirow{2}{*}{$\begin{array}{c}\text { Mono- } \\
\text { saccharides }\end{array}$} & \multirow[t]{2}{*}{ Ratio $^{2}$} & \multirow[t]{2}{*}{ Total P } & \multirow[t]{2}{*}{ Resin $\mathrm{Pi}^{3}$} & \multicolumn{3}{|c|}{$\mathrm{NaHCO}_{3}$-extractable $\mathrm{P}^{4}$} & \multicolumn{3}{|c|}{$\mathrm{NaOH}$-extractable $\mathrm{P}^{5}$} \\
\hline & & & & & & & Total & $\mathrm{Pi}$ & Po & Total & $\mathrm{Pi}$ & Po \\
\hline & $\left(\mathrm{g} \mathrm{kg}^{-1}\right)$ & $\left(\mathrm{g} \mathrm{kg}^{-1}\right)$ & $\left(\mathrm{mg} \mathrm{kg}^{-1}\right)$ & & $(\mathrm{mg} \mathrm{kg}$ & $\left(\mathrm{mg} \mathrm{kg}^{-1}\right)$ & $\left(\mathrm{mg} \mathrm{kg}^{-1}\right.$ & $\left(\mathrm{mg} \mathrm{kg}^{-1}\right.$ & $\left(\mathrm{mg} \mathrm{kg}^{-1}\right)$ & $\left(\mathrm{mg} \mathrm{kg}^{-1}\right)$ & $\left(\mathrm{mg} \mathrm{kg}^{-1}\right)$ & $\left(\mathrm{mg} \mathrm{kg}^{-1}\right)$ \\
\hline \multicolumn{4}{|c|}{ Treatment $^{1}$} & \multicolumn{9}{|c|}{ Stipa-Bouteloua (established 6 Apr. 1994; sampled 22 Apr. 1996) } \\
\hline 1. & 17.9 & 1.84 & 4.84 & 0.51 & 419 & 8.76 & 14.5 & 6.66 & 7.79 & 75.3 & 14.5 & 60.8 \\
\hline 2. & 15.0 & 1.62 & 3.55 & 0.46 & 395 & 5.91 & 13.8 & 5.55 & 8.23 & 73.7 & 11.6 & 62.1 \\
\hline 3. & 14.9 & 1.59 & 3.65 & 0.48 & 407 & 6.66 & 13.4 & 5.79 & 7.61 & 74.4 & 11.9 & 62.5 \\
\hline 4. & 14.8 & 1.60 & 3.62 & 0.48 & 398 & 7.40 & 13.7 & 6.06 & 7.67 & 79.9 & 12.4 & 67.5 \\
\hline 5. & 15.1 & 1.63 & 3.68 & 0.46 & 394 & 6.35 & 12.9 & 5.77 & 7.13 & 70.4 & 11.6 & 58.8 \\
\hline 6. & 15.4 & 1.62 & 3.84 & 0.47 & 406 & 6.41 & 14.0 & 5.85 & 8.10 & 77.8 & 11.9 & 65.9 \\
\hline \multirow[t]{2}{*}{7.} & 15.1 & 1.61 & 3.33 & 0.55 & 370 & 6.70 & 13.4 & 6.50 & 6.90 & 71.8 & 12.5 & 59.4 \\
\hline & \multicolumn{12}{|c|}{ Stipa-Bouteloua-Agropyron (established 1 Apr. 1993; sampled 1 May 1996) } \\
\hline 1. & 39.2 & 3.77 & 8.63 & 0.62 & 684 & 9.75 & 18.5 & 7.73 & 10.8 & 99.2 & 12.1 & 87.1 \\
\hline 2. & 30.4 & 2.88 & 6.65 & 0.55 & 689 & 7.31 & 15.9 & 7.30 & 8.60 & 85.2 & 11.2 & 74.1 \\
\hline 3. & 30.4 & 2.92 & 6.42 & 0.58 & 669 & 7.28 & 15.8 & 7.15 & 8.65 & 83.8 & 11.2 & 72.7 \\
\hline 4. & 29.6 & 2.96 & 6.01 & 0.47 & 666 & 8.54 & 15.7 & 6.66 & 9.01 & 83.7 & 10.9 & 72.8 \\
\hline 5. & 29.6 & 2.91 & 5.54 & 0.46 & 657 & 6.77 & 15.0 & 6.27 & 8.70 & 74.6 & 10.4 & 64.2 \\
\hline 6. & 31.9 & 3.02 & 6.72 & 0.61 & 656 & 7.42 & 15.8 & 7.19 & 8.56 & 88.8 & 11.6 & 77.1 \\
\hline 7. & 30.8 & 2.96 & 6.44 & 0.60 & 665 & 9.68 & 15.0 & 6.88 & 8.14 & 86.1 & 11.8 & 74.3 \\
\hline \multicolumn{13}{|c|}{ Fescue (ungrazed-established 13 Apr. 1993; sampled 6 Jun. 1996) } \\
\hline 1. & 108.5 & 9.74 & 25.6 & 0.70 & 1336 & 31.2 & 80.4 & 16.1 & 64.3 & 678 & 33.0 & 645 \\
\hline 2. & 85.7 & 7.68 & 23.0 & 0.63 & 1247 & 22.5 & 84.4 & 15.0 & 69.5 & 628 & 30.5 & 597 \\
\hline 3. & 79.0 & 6.85 & 19.3 & 0.54 & 1155 & 20.6 & 81.4 & 12.9 & 68.5 & 446 & 31.5 & 414 \\
\hline 4. & 84.9 & 7.03 & 18.8 & 0.58 & 1239 & 24.0 & 91.5 & 15.6 & 75.9 & 527 & 35.3 & 491 \\
\hline 5. & 86.0 & 7.69 & 21.5 & 0.50 & 1234 & 26.0 & 90.8 & 16.6 & 74.2 & 536 & 33.6 & 519 \\
\hline 6. & 91.0 & 7.83 & 20.0 & 0.53 & 1216 & 22.6 & 94.7 & 16.4 & 78.3 & 557 & 37.0 & 520 \\
\hline 7. & 74.8 & 6.30 & 15.7 & 0.52 & 1075 & 22.3 & 68.4 & 16.6 & 51.8 & 494 & 35.5 & 458 \\
\hline \multicolumn{13}{|c|}{ Fescue (grazed-established 13 Apr. 1993; sampled 6 Jun. 1996) } \\
\hline $1 .^{6}$ & 88.8 & 8.38 & 22.6 & 0.71 & 1168 & 20.8 & 72.5 & 10.7 & 61.8 & 598 & 24.8 & 573 \\
\hline 2. & 83.9 & 7.32 & 16.4 & 0.55 & 1145 & 20.6 & 69.8 & 14.4 & 55.1 & 559 & 29.3 & 530 \\
\hline 3. & 80.8 & 7.63 & 16.6 & 0.59 & 1140 & 20.9 & 71.9 & 14.4 & 57.5 & 544 & 28.6 & 516 \\
\hline 4. & 78.5 & 6.99 & 16.2 & 0.67 & 1150 & 20.5 & 80.3 & 13.9 & 66.4 & 622 & 33.5 & 588 \\
\hline 5. & 74.3 & 7.65 & 17.3 & 0.55 & 1137 & 21.9 & 78.8 & 15.8 & 62.9 & 549 & 32.2 & 517 \\
\hline 6. & 82.6 & 7.19 & 17.1 & 0.62 & 1147 & 19.5 & 73.3 & 16.3 & 57.1 & 543 & 32.4 & 511 \\
\hline 7. & 76.9 & 6.45 & 15.9 & 0.55 & 1144 & 21.4 & 78.8 & 16.1 & 62.7 & 505 & 36.4 & 469 \\
\hline $8 .^{7}$ & 80.7 & 7.70 & 15.6 & 0.56 & 1167 & 21.2 & 81.4 & 8.7 & 72.7 & 550 & 25.6 & 525 \\
\hline
\end{tabular}


Table 2. Comparison of the influence of cultivation and modified plant communities on selected soil parameters.

\begin{tabular}{|c|c|c|c|c|c|c|c|c|c|c|c|c|}
\hline & \multirow[t]{2}{*}{$\mathrm{C}$} & \multirow[t]{2}{*}{$\mathrm{N}$} & \multirow{2}{*}{$\begin{array}{c}\text { Mono- } \\
\text { saccharides }\end{array}$} & \multirow[t]{2}{*}{ Ratio $^{2}$} & \multirow[t]{2}{*}{ Total P } & \multirow[t]{2}{*}{ Resin $\mathrm{Pi}^{3}$} & \multicolumn{3}{|c|}{$\mathrm{NaHCO}_{3}$-extractable $\mathrm{P}^{4}$} & \multicolumn{3}{|c|}{$\mathrm{NaOH}$-extractable $\mathrm{P}^{5}$} \\
\hline & & & & & & & Total & $\mathrm{Pi}$ & Po & Total & $\mathrm{Pi}$ & Po \\
\hline & $\left(\mathrm{g} \mathrm{kg}^{-1}\right)$ & $\left(\mathrm{g} \mathrm{kg}^{-1}\right)$ & $\left(\mathrm{mg} \mathrm{kg}^{-1}\right)$ & & & & & & & & & \\
\hline Treatment & & & & \multicolumn{9}{|c|}{ Stipa-Bouteloua (established 6 Apr. 1994; sampled 22 Apr. 1996) } \\
\hline 1 vs 2,3 & $<0.001$ & $<0.001$ & $<0.001$ & 0.002 & 0.004 & $<0.001$ & 0.40 & $<0.001$ & 0.757 & 0.411 & $<0.001$ & 0.346 \\
\hline 2,3 vs 5 & 0.798 & 0.349 & 0.500 & 0.324 & 0.261 & 0.683 & 0.095 & 0.572 & 0.062 & 0.024 & 0.613 & 0.035 \\
\hline \multicolumn{13}{|c|}{ Stipa-Bouteloua-Agropyron (established 1 Apr. 1993; sampled 1 May 1996) } \\
\hline 2,3 vs 5 & 0.176 & 0.910 & $<0.001$ & $<0.001$ & $<0.001$ & 0.016 & 0.027 & 0.002 & 0.865 & $<0.001$ & 0.061 & $<0.001$ \\
\hline \multicolumn{13}{|c|}{ Fescue (ungrazed-established 13 Apr. 1993; sampled 6 Jun. 1996) } \\
\hline 1 vs $2-7$ & $<0.001$ & $<0.001$ & $<0.001$ & $<0.001$ & $<0.001$ & $<0.001$ & 0.003 & 0.185 & 0.001 & $<0.001$ & 0.033 & $<0.001$ \\
\hline 1 vs 2,3 & $<0.001$ & $<0.001$ & $<0.001$ & $<0.001$ & $<0.001$ & $<0.001$ & 0.126 & $<0.004$ & 0.009 & $<0.001$ & $<0.001$ & $<0.001$ \\
\hline 2,3 vs 5 & 0.218 & 0.061 & 0.360 & $<0.001$ & 0.065 & $<0.001$ & $<0.001$ & $<0.001$ & 0.002 & 0.984 & $<0.001$ & 0.045 \\
\hline \multicolumn{13}{|c|}{ Fescue (grazed-established 13 Apr. 1993; sampled 6 Jun. 1996) } \\
\hline $\begin{array}{l}1 \text { = native } \\
\text { Stipa-Boute } \\
2 \text { Galactose } \\
{ }^{3} \mathrm{Resin}^{2} \text { extr } \\
{ }^{4} \mathrm{NaHCO}_{3} \\
{ }^{5} \mathrm{NaOH} \text { ext } \\
{ }^{6} \mathrm{Native} \text { pra } \\
{ }^{7} \text { Native pra }\end{array}$ & $\begin{array}{l}\text { + Mannose } \\
\text { actable } \mathrm{Pi} ; \\
\text { extractable } \\
\text { ractable } \mathrm{P}, \\
\text { irie grazed } \\
\text { irie grazed }\end{array}$ & $\begin{array}{l}\text { ose }+ \text { Aral } \\
\text { norganic } \\
\text { and Po a } \\
\text { Po afte } \\
1949 \text { at } 2 \\
1949 \text { at } 2\end{array}$ & $\begin{array}{l}\text { ose. } \\
\text { resin extrac } \\
\mathrm{aHCO}_{3} \text { extra } \\
\text { animal unit } \mathrm{r}\end{array}$ & $\begin{array}{l}\text { lon; Po }=\text { Or } \\
\text { ction. } \\
\text { lonth ha }{ }^{-1} \text { un } \\
\text { onth ha }{ }^{-1} \text {. }\end{array}$ & $\begin{array}{l}\text { nic P. } \\
13 \text { Apr. } 1993 .\end{array}$ & & & & & ue sites & issi & \\
\hline
\end{tabular}

nitude: Stipa-Bouteloua $<$ StipaBouteloua-Agropyron < grazed fescue < ungrazed fescue.

Cultivating and seeding grasses, alfalfa, and wheat produced a change compared to the Ah horizons in most chemical constituents (Tables 1 and 2). Sodium bicarbonate or sodium hydroxide-extractable total or organic $\mathrm{P}$ were not affected $(\mathrm{P}>$ 0.05 ) by treatment on the Stipa-Bouteloua site and total $\mathrm{P}$ and resin-extractable $\mathrm{Pi}$ was unaffected $(\mathrm{P}>0.05)$ by treatment on the grazed Fescue Prairie site. These results were consistent in a comparison of native with all other treatments or native with only the grass treatments (Tables 1 and 2).

The chemical constituents in soils of 2 grass species were mostly similar $(\mathrm{P}>$ $0.05)$ with continuous wheat in the StipaBouteloua site but tended to differ in the $\mathrm{P}$ constituents of the Stipa-BoutelouaAgropyron and Fescue Prairie sites (Tables 1 and 2). Harvesting fescue grassland on the grazed site reduced $(\mathrm{P}<0.05)$ soil $\mathrm{C}$, $\mathrm{N}$, monosaccharides, sodium bicarbonate $\mathrm{Pi}$, and sodium hydroxide total and organic $\mathrm{P}$ while increasing sodium bicarbonate total and organic P (Tables 1 and 2).

The water-stable aggregate fractions that remained on the 2.0 and $1.0 \mathrm{~mm}$ sieves tended to be greater in the native grassland soils than in the cultivated treatments (Table 3 ). In the ungrazed native Fescue
Prairie site the proportion tended to be similar $(\mathrm{P}=0.073)$ to all other treatments combined. The proportion of water-stable aggregates of the native soil were similar $(\mathrm{P}=0.612)$ to the perennial grass treatments only on the Stipa-BoutelouaAgropyron site. The proportion of water-

stable aggregates in soil of the perennial grasses was different $(\mathrm{P}<0.05)$ from soil of continuous wheat in the StipaBouteloua-Agropyron and ungrazed native Fescue Prairie sites but similar $(\mathrm{P}>0.05)$ on the other sites (Table 3).

Table 3. Water-stable aggregate fraction that remained on the 2.0 and $1.0 \mathrm{~mm}$ sieves as percent of total from undisturbed and modified prairie at 4 research sites.

\begin{tabular}{|c|c|c|c|c|}
\hline & $\begin{array}{c}\text { Stipa- } \\
\text { Bouteloua }\end{array}$ & $\begin{array}{c}\text { Stipa- } \\
\text { Bouteloua } \\
\text { Agropyron }\end{array}$ & Enclosure & Grazed $^{1}$ \\
\hline Treatment & \multicolumn{4}{|c|}{ 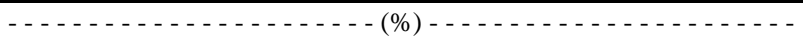 } \\
\hline Native, ungrazed (1) & 23.8 & 43.4 & 44.2 & 48.3 \\
\hline Crested wheatgrass (2) & 11.8 & 46.9 & $33.2^{2}$ & $43.8^{2}$ \\
\hline Russian wildrye (3) & 10.5 & 42.8 & $33.7^{3}$ & $37.2^{3}$ \\
\hline Wheat, fallow (4) & 8.6 & 31.9 & 43.0 & 43.2 \\
\hline Wheat, continuous $(5)$ & 14.4 & 36.6 & 43.6 & 46.4 \\
\hline Alfalfa (6) & 15.7 & 35.2 & 30.9 & 42.4 \\
\hline Abandoned cultivation (7) & 11.8 & 32.3 & 31.3 & 30.8 \\
\hline Native, grazed $^{4}(8)$ & & & & 44.8 \\
\hline $\mathrm{Avg}^{5}$ & $13.8^{\mathrm{a}}$ & $38.4^{\mathrm{c}}$ & $36.7^{\mathrm{b}}$ & $41.7^{\mathrm{d}}$ \\
\hline \multicolumn{5}{|l|}{$\underline{\text { Contrasts }}$} \\
\hline Trt. 1 vs 2 to 7 & $<0.001$ & 0.035 & 0.073 & 0.011 \\
\hline Trt. 1 vs 2 and 3 & $<0.001$ & 0.612 & 0.032 & 0.028 \\
\hline Trt 1 vs 7 & $<0.001$ & 0.004 & 0.017 & $<0.001$ \\
\hline Trt. 2 and 3 vs 5 & 0.156 & 0.010 & 0.010 & 0.090 \\
\hline Trt. 1 vs 8 & & & & 0.358 \\
\hline
\end{tabular}

$1=$ native prairie grazed since 1949 at 2.4 animal unit month ha- ${ }^{-1}$ until 13 Apr. 1993 .

2 orchard grass

3 smooth bromegrass

${ }^{4}$ native prairie grazed since 1949 at 2.4 animal unit month ha ${ }^{-1}$

5 means in row having the same letter do not differ significantly $(P>0.05)$. 


\section{Discussion}

The short-term changes in soil quality of the Ah or Ap horizon are heavily influenced by soil mixing and to a much lesser extent by the new plant community. Nevertheless, they do provide a benchmark from which to examine subsequent genesis and an opportunity to compare the contribution to soil quality between different cultivated communities. Too many studies look only at the long-term differences and then hypothesise soil mixing effects.

Many changes occurred among the soil parameters measured the moment native prairie was converted to cultivated land. Losses of total C, N, P, water-stable aggregates, and monosaccharides were immediate. The polysaccharides changed towards being more of plant origin, i.e., increased levels of xylose and galactose. Cultivation and reseeding produced significant short-term effects on the $\mathrm{C}, \mathrm{N}$, and $\mathrm{P}$ parameters in all 4 sites that were influenced by the new plant community.

Biological activity parameters have been shown to be sensitive indicators of withinsite temporal and soil quality changes (Dormaar and WilIms 2000). In the present study, $\mathrm{P}$ was selected as a potentially useful parameter since it serves as an indicator in investigations of pedogenetic processes with essentially the only source of soil $\mathrm{P}$ being weathered primary minerals of the parent material. The loss of total $\mathrm{P}$ results from a combination of soil mixing and plant removal during the preparation of the site for the various treatments.

Harvesting above-ground dry matter is a common pathway for nutrient loss on anthropocentrically managed land. It shows up in this study, because we examined it at the moment of a major change well prior to the development of new steady states.

An examination of annual loss of resin-, $\mathrm{NaHCO}_{3^{-}}$, and $\mathrm{NaOH}$ extractable $\mathrm{P}$ through the removal of above ground biomass may well have to be carried out in the future to get a better understanding of $\mathrm{P}$ cycling. The distribution and flow of the more labile forms of $\mathrm{P}$ can provide a valuable index to the levels and kinds of biological activity in an ecosystem (Cole et al. 1977). Given enough time, the new root systems of the various treatments will bring up and process $\mathrm{P}$ again from the parent material. It will then be of interest to determine the total mass of $\mathrm{P}$ in a soil profile to the depth of the various root masses. It may also confirm on a field scale the conclusion reached in growth chambers that rhizospere changes in $\mathrm{P}$ and phos- phatase activity levels are a function of plant species and soil type (Dormaar 1988, McKenzie et al. 1995). Within the 6 cultivated treatments it is clear that the presence of vegetation, even via partially intact root mass, is already indicative of a plant-soil interaction.

The percent $\mathrm{Pi}$ (i.e., resin $+\mathrm{NaHCO}_{3}+$ $\mathrm{NaOH}$ ) of total $\mathrm{P}$ within all treatments was more or less identical to that of the native prairie. Conversely, the difference between the native prairie vs the cultivated plots for percent $\mathrm{Po}\left(\mathrm{NaHCO}_{3}+\mathrm{NaOH}\right)$ of total $\mathrm{P}$ was 16 vs 18,14 vs 12 , and 53 vs 48 for the ungrazed Brown, Dark Brown, and Black Chernozemic soils, respectively, and 54 vs 51 for both the recovering native prairie vs cultivated treatments and recovering native prairie vs grazed native prairie. It can be hypothesized that, at least for the Black Chernozemic site, the increased root mass and litter (Porter et al. 1999) and thus increased microbiological population, is in part responsible for the higher levels of Po under native prairie.

Root mass is not necessarily a measure of active, metabolically functional root tissue. In fact, it has been shown (Dormaar and Ketcheson 1960) that finely ramified root mass, and thus with increased potential to foster microbial growth and activity in their rhizospheres, can actually be of lesser weight than coarse roots with less root hairs. Further, the introduced grasses and wheat were sown in rows. The soil was not as yet filled with ramifying root mass as under native prairie. This then may help to explain some of the changes observed.

The loss of the water-stable aggregate fraction that remained on the 2.0 and 1.0 mm sieves $(>2.0+>1.0 \mathrm{~mm})$ as percent of total water-stable aggregates is in part the result of loss of organic binding agents ranging from short-chain organic molecules, such as polysaccharides, to plant roots. Polysaccharides are considered to be an organic binding agent of transient persistence (Tisdall and Oades 1982), while roots and bacterial cells can be classified as having more of temporary persistence. With decreased root mass (Porter et al. 1999) a potential mechanical framework for the formation and initial stabilization of macroaggregates (Elliott and Coleman 1988) is lost. To restore a stable macroaggregate structure, the direct and indirect effects of roots and external hyphae will be essential (Jastrow etal. 1998).

Many other parameters could have been selected. One of these could have been lit- ter mass. However, it was too soon for the cultivated and resown plots to have any litter buildup as yet. Attention can be called to the effect of above- and belowground litter at a future examination of the experiment. Once the introduced grasses and legume have had a chance to approach a steady state, a careful examination of fine root structure vs root mass per se, together with potential energy available for microbial processes, may be on. At that time, clipping of half the plots will further enhance insight into the strong influence of roots on soil chemical and biochemical processes. This would then be a simulation of grazing, even though it does not uncouple the $\mathrm{N}$ pathway, through standing dead to litter, decomposers, and soil organic matter, in the presence of large animals by removing part of the $\mathrm{N}$ in grazing and returning it in urine and faeces.

Two interacting factors strongly influence chemical and biological processes on rangelands. Herbivory impacts carbon flow to roots and transfer of nutrients offsite. Species composition impacts nutrient cycling and soil biochemical processes related to rhizosphere interactions. Our research attempted to isolate single species vegetation factors that influence soil physical and chemical characteristics. Moreover, we wanted to determine the time frame in which measurable changes in soil characteristics occurred due to the influence of a particular plant species. Our data show that in as little as 3 years, a specific species can significantly alter soil chemical and physical attributes relative to a native grassland. These results suggest that trajectories of soil evolution can be radically altered depending on the nature of vegetation occupying the soil. This approach can be criticized as being reductionist, since it does not relate to the effect of mammal herbivore superimposition. This criticism is valid particularly in the light of the literature review regarding the potential belowground changes possible following defoliation by grazing (Johnston 1961, Manske 1995). Nevertheless, it seemed logical to us to understand the effect of various soil-plant manipulations first before dealing with the further complexity added by the effects of grazing by mammal herbivores.

\section{Literature Cited}

Blakeney, A.B., P.J. Harris, R.J. Henry, and B.A. Stone. 1983. A simple and rapid preparation of alditol acetates for monosaccharide analysis. Carbohydr. Res. 113:291-299. 
Cheshire, M.V. 1979. Nature and origin of carbohydrates in soils. Academic Press, Inc., New York, N.Y.

Cheshire, M.V. and C.M. Mundie. 1966. The hydrolytic extraction of carbohydrates from soil by sulphuric acid. J. Soil Sci. 17:372-381.

Cole, C.V., G.S. Innis, and J.W.B. Stewart. 1977. Simulation of phosphorus cycling in semiarid grasslands. Ecol. 58:1-15.

Coupland, R.T. 1961. A reconsideration of grassland classification in the northern Great Plains of North America. J. Ecol. 49:135-167.

Dormaar, J.F. 1984. Monosaccharides in hydrolysates of water-stable aggregates after 67 years of cropping to spring wheat as determined by capillary gas chromatography. Can. J. Soil Sci. 64: 647-656.

Dormaar, J.F. 1988. Effect of plant roots on chemical and biochemical properties of surrounding discrete soil zones. Can. J. Soil Sci. 68:233-242.

Dormaar, J.F. and J.W. Ketcheson. 1960. The effect of nitrogen form and soil temperature on the growth and phosphorus uptake of corn plants grown in the greenhouse. Can. J. Soil Sci. 40:177-184.

Dormaar, J.F. and W.D. Willms. 1998. Effect of forty-four years of grazing on fescue grassland soils. J. Range Manage. 51: 122-126

Dormaar, J.F. and W.D. WilIms. 2000. Impact of rangeland management on soil biological 2 indicators in southern Alberta. J. Range Manage 53:233-238.
Elliott, E.T. and D.C. Coleman. 1988. Let the soil work for us. Ecol. Bull. 39:23-32.

Hedley, M.J., J.W.B. Stewart, and B.S. Chauhan. 1982. Changes in inorganic and organic phosphorus fractions induced by cultivation practices and by laboratory incubations. Soil Sci. Soc. Amer. J. 46:970-976.

Jastrow, J.D., R.M. Miller, and J. Lussenhop. 1998. Contributions of interacting biological mechanisms to soil aggregate stabilization in restored prairie. Soil Biol. Biochem. 30:905-916.

Johnston, A. 1961. Comparison of lightly grazed and ungrazed range in the fescue grassland of southwestern Alberta. Can. J. Plant Sci. 41: 615-622.

Jenkinson, D.S. 1991. The Rothamsted longterm experiments: Are they still of use? Agron. J. 83:2-10.

Kemper, W.D. and E.J. Koch. 1966. Aggregate stability of soils from western United States and Canada: measurement procedure and correlation with soil constituents. Agr. Res. Service, USDA Tech. Bull. No. 1355.

Kemper, W.D. and R.C. Rosenau. 1986. Aggregate stability and site distribution. In: A.Klute (ed.), Methods of soil analysis. Part 1. Physical and mineralogical methods. Agron. 9:425-442. Amer. Soc. Agron., Madison, Wis.

Manske, L.L 1995. Adaptive tolerance mechanisms in grass plants, p. 97-99. In: Z.Abouguendia (ed.), Proc. Grazing and Pasture Technology Program Conference, Swift Current, S.K. Saskatchewan Agr. and Food, Regina, SK.
McKenzie, R.H., J.F. Dormaar, B.B. Schaalje, and J.W.B. Stewart. 1995. Chemical and biochemical changes in the rhizospheres of wheat and canola. Can. J. Soil Sci. 75: 439-447.

Mitchell, C.C., R.L. Westerman, J.R. Brown, and T.R. Peck. 1991. Overview of long-term agronomic research. Agron. J. 83:24-29.

Moss, E.G. and J.A. Campbell. 1947. The fescue grassland of Alberta. Can. J. Res. C25:209-227.

Porter, S., W.D. WilIms, J.F. Dormaar, B.H. Ellert, and H.H. Janzen. 1996. Agricultural effects on primary production and soils of a Mixed Prairie ecosystem. Proc. Fifth Intl. Rangeland Congr. Vol. 1: 448-449.

Porter, S.W., W.D. WilIms, J.F. Dormaar, B.H. Ellert, and H.H. Janzen. 1999. Short term soil and production changes created by cultivating native Mixed Prairie in the Northern Great Plains. Soc. Range Manage./Amer. Forage Grassl. Counc. Abstr. 52:64.

Schimel, D., M.A. Stillwell, and R.G. Woodmansee. 1985. Biogeochemistry of C, $\mathrm{N}$, and $\mathrm{P}$ in a soil catena of the shortgrass steppe. Ecol. 66: 276-282.

Steel, R.G.D. and J.H. Torrie. 1980 . Principles and procedures of statistics: A biometrical approach. McGraw Hill Book Co., New York, N.Y.

Tisdall, J.M. and J.M. Oades. 1982. Organic matter and water-stable aggregates in soils. J. Soil Sci. 33:141-163. 